\title{
DESENVOLVIMENTO E CONSTRUÇÃO DE BLOCOS DE CONCRETO RADIOATIVO PARA A CALIBRAÇÃO DE ESPECTRÔMETROS GAMA PORTÁTEIS E AEROTRANSPORTADOS, UTILIZADOS EM EXPLORAÇÃO MINERAL E DE HIDROCARBONETOS
}

\author{
Dionísio Uendro Carlos \\ Orientadora: Dr. Fernando Brenha Ribeiro (IAG-USP) \\ 92 p. - Dissertação (Mestrado) - Defesa 14.03.2006
}

RESUMO. Oito blocos transportáveis para calibração foram construídos para serem utilizados como padrões de concentração na calibração de espectrômetros gama portáteis e aerotransportados. Todo o procedimento de construção é descrito em detalhe. Os blocos, com dimensões de $1 \mathrm{~m}$ $\times 1 \mathrm{~m} \times 0,30 \mathrm{~m}$ e massas variando entre $593 \mathrm{~kg}$ e $673 \mathrm{~kg}$, devem a sua radioatividade à adição de diferentes quantidades de feldspato potássico (ortoclásio), caldasito e areia monazítica à massa de concreto. As concentrações de potássio, urânio e tório variam significativamente de um bloco para outro atingindo valores máximos de 5,7\% de K, 45,6 ppm eU e 137 ppm eTh. A distribuição do fluxo de radiação gama proveniente da superfície dos blocos de concreto e a magnitude das heterogeneidades na concentração dos elementos radioativos foram determinadas experimentalmente. Como exemplo de aplicação apresenta-se o resultado da calibração de um espectrômetro gama portátil.

ABSTRACT. Eight transportable calibration pads were built in to be used as concentration standards for portable and airborne gamma-ray spectrometers calibrations. The pads construction procedure is described in full detail. The pads, with dimensions of $1 \mathrm{~m} \times 1 \mathrm{~m} \times 0.30 \mathrm{~m}$ and masses between $593 \mathrm{~kg}$ and $673 \mathrm{~kg}$ were made radioactive by the addition of different amounts of $\mathrm{k}$-feldspar, caldasite and monazitic sand to the concrete masses. The potassium, uranium and thorium concentration vary significantly in the pads, reaching maximum values of 5,7\% of K, 45,6 ppm eU and $137 \mathrm{ppm}$ eTh. The distribution of the gamma radiation flux from the pads surfaces and the heterogeneity magnitudes of the radioactive elements concentration were experimentally established. An example of gamma-ray spectrometer calibration is presented. 